\title{
N Absorption in Nontidal Rice Fields Treated with Microalgae and Nitrogen Fertilizer Application
}

\author{
DOI: 10.18196/pt.2019.089.19-25
}

\author{
Nova Tri Buyana*, Nuni Gofar, A. Madjid Rohim \\ Graduate School Faculty of Agriculture, Universitas Sriwijaya, Palembang, Indonesia \\ Jl Srijaya Negara - Jl Padang Selasa No.524, Bukit Lama, Ilir Barat I, Palembang, South Sumatra 30139, Indonesia \\ *Corresponding author, email: aya_noone@yahoo.co.id
}

\begin{abstract}
Nutrient elements that are needed by plants during its growth and development is nitrogen. Nitrogen deficiency can cause plants to become necrosis so that plants are not able to photosynthesize well, thus result in lack of food needed by plants. Microalgae can provide nitrogen for rice crops due to its activity. The aim of this research was to know the effect of microalgae from nontidal swamp land to reduce the use of inorganic $N$ fertilizer in paddy field. The study was conducted from January to April 2017, using factorial completely randomized design with two factors, namely isolate and dosage of nitrogen fertilizer. The first factor is the type of the isolate (I), consisting of cultures from the area of rice cultivation (I1), the culture originating from the area around the rice fields (I2) and the cultures of area without rice cultivation (I3) area. The second factor is the dose of nitrogen fertilizer (N) consisting of 0\%, 50\% and 100\%. The results showed that the treatment of the isolate (I) or dosage of nitrogen fertilizer had a significant effect on the weight of 1000 filled grains and the weight of empty grains in the generative phase of rice plant. The interaction between both treatments had a significant effect on the generative (production) phase. The microalgae culture from area of rice cultivation (11) can contribute nitrogen requirement of 16.23\% - 48.71\% with an abundance of 7.48 cells $\mathrm{ml}^{-1}$, with the requirement of rice plant nitrogen fertilizer of 45-135 $\mathrm{kg} \mathrm{ha-1}^{-1}$
\end{abstract}

Keywords: Microalgae, nitrogen, lowland rice, nontidal swamp land

\section{ABSTRAK}

Unsur hara yang dibutuhkan oleh tanaman selama pertumbuhan dan perkembangannya adalah nitrogen. Kekurangan nitrogen dapat menyebabkan tanaman menjadi nekrosis sehingga tanaman tidak dapat berfotosintesis dengan baik sehingga mengakibatkan kekurangan makanan yang dibutuhkan oleh tanaman. Mikroalga mampu menyediakan nitrogen untuk tanaman padi karena aktivitasnya. Tujuan dari penelitian ini adalah untuk mengetahui pengaruh mikroalga dari lahan rawa lebak untuk mengurangi penggunaan pupuk N anorganik di sawah. Penelitian dilakukan dari Januari hingga April 2017, menggunakan rancangan acak lengkap faktorial dengan dua faktor, yaitu isolat dan dosis pupuk nitrogen. Faktor pertama adalah jenis isolat (I), yang terdiri dari kultur dari area budidaya padi (11), budaya yang berasal dari daerah di sekitar sawah (I2) dan budaya daerah tanpa budidaya padi (I3). Faktor kedua adalah dosis pupuk nitrogen (N) yang terdiri dari 0\%, 50\% dan 100\%. Hasil penelitian menunjukkan bahwa perlakuan isolat (I) atau dosis pupuk nitrogen berpengaruh signifikan terhadap bobot 1000 butir yang terisi dan berat butir kosong pada fase generatif tanaman padi. Interaksi antara kedua perlakuan memiliki efek signifikan pada fase generatif (produksi). Kultur mikroalga dari areal budidaya padi (11) dapat menyumbang kebutuhan nitrogen 16,23\% - 48,71\% dengan kelimpahan 7,48 sel ml-1, dengan kebutuhan pupuk nitrogen tanaman padi 45-135 kg ha-1..

Kata Kunci: Mikroalga, Nitrogen, Padi sawah, Rawa lebak

\section{INTRODUCTION}

Nitrogen has a major role in the growth of stems and leaves of plants. According to Alavan et al. (2015), $\mathrm{N}$ is needed in most of the plant growth, such as plant height, number of tillers and leaf size. Soil capacity in supplying, binding and removing nutrients may affect the plant in obtaining nutrient sources and fertilizer mobility to be used. Rice crops can obtain nitrogen from the fixation of algae and heterotrophic bacteria, mineralization of organic materials and $\mathrm{N}$ reserves in the soil. Rice plant, in its growth, requires about $14.7 \mathrm{Kg} \mathrm{N} ; 2.6 \mathrm{~kg} \mathrm{P}$ and $14.5 \mathrm{~kg} \mathrm{~K} /$ ha which can be obtained from soil, irrigation water, crop residues or from organic (and inorganic) fertilizers added. (Abdulrachman et al., 2009).

Inorganic fertilizers added to the plant are valuable components that are needed by plant growth, but are able to contribute to environmental pollution. The use of microalgae that has a green leaf dye (pigment) playing a role in the photosynthesis with the help of $\mathrm{H}_{2} \mathrm{O}, \mathrm{CO}_{2}$ and sunlight to produce energy is very useful in cell biosynthesis, cell growth, 
and reproduction in plants (Sari, 2011). Sopiah et al. (2012) states that microalgae are single-celled microscopic plants living in aquatic environments that grow and develop by utilizing sunlight as a source of energy, inorganic nutrients such as $\mathrm{CO}_{2}$, dissolved nitrogen, and phosphate components.

Winahyu et al. (2013), state that microalgae are very valuable as resources with unique characteristics and uniqueness that can be utilized for various applications. For example, microalgae able to capture $\mathrm{N}_{2}$ from the air can be used as green manure in agriculture and bioremediation. Coleman (2001) further states that soil microalgae can survive in critical condition, thus able to loosen the soil. Microalgae have the potential to contribute some nutrients such as nitrogen since microalgae can cause some nutrients in the water to be dissolved, then the element will be used by microalgae as nutrition (Fadilah and Ariesyadi, 2013).

Chlorella sp. is one of the cosmopolitan microalgae acting as a source of nitrogen which mostly live in an aquatic environment of freshwater, marine, and brackish waters, found on the ground and in damp places. Microalgae of Chlorella sp. contain various nutrients such as proteins, carbohydrates, unsaturated fatty acids, vitamins, chlorophyll, enzymes, and high fiber (Sitorus et al., 2017).

Microalgae have heterocyst cells by blocking nitrogen from air capable of fixing nitrogen. The ability to add nitrogen is present in Cyanophyta group algae. Heterocyst is a typical cell formed from the development of vegetative cells and is characterized by pole nodules, thick cell walls and homogeneous contents when observed under a light microscope (Nagasathya and Thajuddin, 2008). Heterocyst in Cyanophyta is present in Cyanophyta with filamentous form except Oscillatoriaceae. Sari (2011) states that microalgae with their ability to block nitrogen such as blue-green algae can fertilize their habitat or benefit other organisms that are symbiotic with it. Blue-green algae produce heterocyst in the form of yarn with a size larger than the nearby cell with thicker cell wall.

The amount of heterocyst can increase when nitrogen in the environment is limited. According to Thajuddin \& Subramanian (2005), Cyanophyta has the ability as a biofertilizer to combat soil pollution and to form a symbiotic relationship with rice plants. Lestari (2017) Some members of Cyanophyta have demonstrated their ability to bind nitrogen in the air and to maintain the amount of nitrogen in the soil, where the best conditions for Cyanophyta is generally at pH 7.0-8.5 (Lestari, 2017).

Microalgae can grow well in swamps or paddy fields, either in water or in soil. This is because swamp lands provide the nutrients needed by microalgae to live without disturbing the plants that grow around them. Rice crops obtain sources of nitrogen derived from ammonium and nitrate contained in flooded soils, mineralization of organic materials, nitrogen fixation by algae and bacteria as well as from fertilizers. The results of research in Iran by Soltani et al., (2007) suggest that paddy is a site with favorable conditions for biological nitrogen fixation and microalgae development. The amount of nitrogen biologically fixed is the largest among all fixation processes of $\mathrm{N}_{2}$ atmospheres into ammonium ions indicating the presence of organisms capable of converting $\mathrm{N}$ unavailable to $\mathrm{N}$ available, especially in swamplands (Lestari, 2017).

Based on the results of research by Gofar et al. (2017), microalgae species are common in rice cultivation areas. Observation of microalgae from nontidal swamp land which have been cultured on artificial media obtained 5 micro algae species from 2 microalgae classes. Sari (2011) found 14 species of microalgae from the genus of Cyanophyta in paddy fields. Kasrina et al., (2012) found 4 classes and 32 species of microalgae from swamp water. 
The effect of Cyanobacteria microalgae application to rice plants (Oryza sativa $\mathrm{L}$ ) has been studied by Damaso et al. (2003) using a mixed Cyanobacteria inoculum in the form of Anabaena inyengarii, Nostoc commune, N.linckia and Nostoc sp.1 with a dose of $60 \mathrm{~g} / \mathrm{ha}$. The singleform of microalgae in Amanina's (2011) study using Nostoc had an effect on both vegetative and generative growth of rice crops. Based on the description above it is necessary to know the potential of microalgae collected from swamp land and their influence on reducing the use of inorganic nitrogen fertilizer in nontidal rice fields.

\section{MATERIALS AND METHODS}

Isolation and Selection

Isolation and selection of microalgae were carried out in Laboratory of Soil Biology, Sriwijaya University. Isolates were taken from the area of rice cultivation, the area around the rice cultivation and areas without rice cultivation. The microalgae obtained, then were propelled using Johnson media i.e. magnesium sulfate $0.5 \mathrm{gl}^{-1}$, magnesium chloride $0.2 \mathrm{gl}^{-1}$, potassium nitrate $1.0 \mathrm{gl}^{-1}$, potassium chloride $0.2 \mathrm{gl}^{-1}$, sodium chloride $27 \mathrm{gl}^{-1}, 1 \mathrm{ml} / 1$ of iron (III) chloride-EDTA solution $(1 \mathrm{ml} / \mathrm{l}=0.085 \mathrm{~g}$ iron (III) chloride and $2.67 \mathrm{~g}$ EDTA dissolved in $100 \mathrm{~mL}$ of aquadest), micro element $1 \mathrm{ml} / 1$ (manganese chloride $1.81 \mathrm{~g}$, boric acid $2.86 \mathrm{~g}$, and $0.079 \mathrm{~g}$ of copper (II) sulfate pentahydrate, $0.018 \mathrm{~g}$ of ammonium molybdate, zinc sulfate dihydrate $0.22 \mathrm{~g}$ and dissolved in $100 \mathrm{ml}$ of aquadest) (Agustini, 2002). Growing medium was made by adding $10 \mathrm{ml}$ of each stock solution into 1liter Erlenmeyer flask, then added with sterile distilled water.

\section{Planting Preparation}

Rice seeds were soaked in water for 24 hours. Floating rice seeds were separated, while the sinks were taken. The seeds with the same size were selected. The selected seeds were sown in buckets containing swampy soil, then 2-week rice seedlings were taken as many as 3 rods to be moved and planted into a bucket containing $10 \mathrm{~kg}$ of soil from nontidal land.

Rice plants, during the vegetative stage, were inundated as high as $0.5 \mathrm{~cm}$ from the soil surface, while during the generative stage of rice, were flooded to a height of $2 \mathrm{~cm}$ from the soil surface. Fertilizer application was done in accordance with the recommended dosage of fertilizer for rice plants from Permentan / OT.140 / 4/2007 i.e. urea 250 $\mathrm{kg} \mathrm{ha}^{-1}$, SP-36 $75 \mathrm{~kg} \mathrm{ha}^{-1}$, and KCL $50 \mathrm{~kg} \mathrm{ha}^{-1}$ with the same treatment on each unit trial. Urea fertilizer was given as much as twice the required dosage before planting and 21 days after planting (dap), while SP-36 and KCL fertilizer were given at the same time as the required dosage. Dosage nitrogen fertilizer was given with three different content as a second factor, $0 \%, 50 \%$, and $100 \%$ of the dosage.

The multiplicated microalgae was given at 15 days after planting as much as $45 \mathrm{ml}$ with a density of 106 cells per $\mathrm{ml}$. The microalgae were coming from three different places, isolate from the rice cultivation area (I1), culture isolate from the area surrounding rice fields (I2) and culture isolate from non-planted area (I3). Rice was harvested, when the fruit was matured marked with yellow rice grain, at 115 days after planting (Mezuan et al., 2002).

\section{Observation}

The variables observed were $\mathrm{N}$ concentration in plant (\%), N uptake (g/clump), number of productive tillers, panicle length, percentage of unhulled grain, weight of empty grain, 1000 grains of filled rice grains and production (ton.ha ${ }^{-1}$ ).

\section{Data analysis}

The experimental design used was factorial completely randomized design with two factors. 
Data were analyzed by F test (ANOVA) to see the effect of treatment factor and its interaction and if significant effect was observed, the data then were tested using Least Significant Difference (LSD) test at $5 \%$.

\section{RESULTS AND DISCUSSION}

The soil used as the growth medium is acidic $(\mathrm{pH}=4.22)$ containing very high organic $\mathrm{C}$ reaching $23.94 \%$, high total $\mathrm{N}$ of $1.23 \mathrm{~g} . \mathrm{kg}^{1}$, low available P (Bray I) of $6.15 \mathrm{mg} . \mathrm{kg}^{-1}$, Al-dd of $3.28 \mathrm{cmol}$. $\mathrm{kg}^{1}$, and $\mathrm{H}$-dd of $0.40 \mathrm{cmol} . \mathrm{kg}^{1}$.

The treatment of $\mathrm{N}$ fertilizer dosage significantly affected $\mathrm{N}$ concentration in plant and $\mathrm{N}$ absorption, whereas the treatment of isolate type and the interaction of both treatments had no significant effect on the variables. The LSD test results (Table 1) showed that $N$ concentrations of rice crops fertilized with $50 \%$ and $100 \%$ were not significantly different, but both caused different $\mathrm{N}$ concentration compared to that of plants non-fertilized. The $\mathrm{N}$ uptake was different due to different $\mathrm{N}$ fertilizer dosage in which the highest $\mathrm{N}$ uptake was obtained by rice crops fertilized with $100 \% \mathrm{~N}$ fertilizer.

Table 1. Effect of isolate types and dosage of $\mathrm{N}$ fertilizer on plant nitrogen concentration and N uptake (g/clump)

\begin{tabular}{lcc}
\hline Treatment & $\begin{array}{c}\% \\
\text { Nitrogen }\end{array}$ & $\begin{array}{c}\text { N Absorption } \\
\text { (g/clump) }\end{array}$ \\
\hline $\begin{array}{l}\text { Types of isolates } \\
\text { Isolate I }\end{array}$ & 1.39 & 0.30 \\
Isolate II & 1.52 & 0.38 \\
Isolate III & 1.57 & 0.36 \\
Dosage of Nitrogen & & \\
Without N Fertilizer & $1.58 \mathrm{~b}$ & $0.26 \mathrm{a}$ \\
N 50\% & $1.44 \mathrm{a}$ & $0.35 \mathrm{~b}$ \\
N 100\% & $1.46 \mathrm{a}$ & $0.43 \mathrm{c}$ \\
\hline LSD 0.05 & 0.018 & 0.013 \\
\hline
\end{tabular}

Remarks: Values followed by the same letters are not significantly different at the $5 \%$ LSD test

The highest nitrogen content and $\mathrm{N}$ uptake affected by the isolate types were observed in
Table 2. The main influence of isolate types and nitrogen dosage on the number of productive tillers and the panicle length in the generative phase

\begin{tabular}{lcc}
\hline Treatment & $\begin{array}{c}\text { Number of } \\
\text { productive tillers }\end{array}$ & $\begin{array}{c}\text { Panicle length } \\
(\mathrm{cm})\end{array}$ \\
\hline Types of isolates & 34 & 22.7 \\
Isolate I & 35 & 24.0 \\
Isolate II & 35 & 23.6 \\
Isolate III & & \\
Dosage of Nitrogen & $33 \mathrm{a}$ & 23.8 \\
Without N Fertilizer & $34 \mathrm{~b}$ & 23.3 \\
N 50\% & $36 \mathrm{c}$ & 23.2 \\
N 100\% & 0.311 & 0.087 \\
\hline LSD 0.05 & & \\
\hline
\end{tabular}

Remarks: Values followed by the same letters are not significantly different at the $5 \%$ LSD test

the treatment of the culture isolate III from the non-planted area reaching $1.57 \%$ and the culture type II originating from the rice cultivation area reaching $0.38 \mathrm{~g} /$ clump, respectively. The highest $\mathrm{N}$ concentration and $\mathrm{N}$ uptake as affected by the dosage of $\mathrm{N}$ fertilizer were observed in the plants without $\mathrm{N}$ fertilizer $(1.58 \%)$ and $100 \% \mathrm{~N}$ fertilizer (0.43 g/tiller), consecutively. There was a direct effect of the isolates given to rice crops indicated by a high percentage of nitrogen even without the use of $\mathrm{N}$ fertilizer. Plants obtain a nitrogen supply from microalgae activities. Most of the microalgae that can be found in the rice fields are Cyanophyta species which are nitrogen fixing species such as Anabaena, Calothrix, Fischerella, Nostoc, and Scytonema (Sari, 2011).

The treatment of $\mathrm{N}$ fertilizer dosage significantly influenced the number of productive tillers but the isolates type had no significant effect on the number of productive tillers and the panicle length in the generative phase of the rice plant. The result of LSD test showed that the effect of $\mathrm{N}$ fertilizer dosage was significantly different from one another. The highest number of tillers was observed at $100 \%$ dose (Table 2) showing that microalgae in rice crops added nitrogen element to the growth 
of the number of productive tillers of rice plants, in this case nitrogen plays a role in the process of cell division and elongation. Nitrogen also plays a role in the growth and elongation of the roots so that rice plants lacking nitrogen have fewer tillers and restricted growth (dwarfism) (Amanina, 2011).

The ability of saplings to become productive tillers is influenced by the availability of photosynthates and mineral nutrients. The effect of nitrogen on photosynthetic rate is reasonably suspected to transform the vegetative organ of the stem into a generative organ (flower). Anggraini F et al. (2013) states that the growth of the number of panicles per rice plant will affect the yield of dry grain production with different density. According to Mohanan and Mini (2008), total crop productivity is determined by the ability to produce rice panicles and productivity levels of each panicle. Recent appearances, such as tertiary males, contribute less to yield.

\section{Yield Component}

Types of isolates significantly affected the percentage of empty grain, the weight of filled grains and the weight of 1000 filled grains, but there was no significant effect on production. Meanwhile, the dosage of $\mathrm{N}$ fertilizer had a significant effect on the weight of filled grains, 1000 filled grains and production, but there was no significant effect on the percentage of empty grain.

The highest weight of unhulled grain, the highest percentage of unhulled grain and the highest weight of 1000 grains of rice as affected by the type of isolate were observed in culture I (0.29\%), culture III (2.78 gr / clump) and culture II (29.76 gr), respectively. The weight of unhulled grains and 1000 grains of rice fertilized with no N and 100\% $\mathrm{N}$ were not significantly different, but the weight of filled grains and 1000 filled grains of with $\mathrm{N}$ $50 \%$ fertilizer.
Table 3. Effect of isolate types and dosage of $\mathrm{N}$ fertilizer on the yield component of rice crop

\begin{tabular}{lcccc}
\hline Treatment & $\begin{array}{c}\% \\
\text { empty } \\
\text { grain }\end{array}$ & $\begin{array}{c}\text { Grain } \\
\text { weight } \\
\text { (gr/ } \\
\text { clump) }\end{array}$ & $\begin{array}{c}\text { Weight } \\
\text { of } 1000 \\
\text { filled } \\
\text { grains } \\
\text { (gr) }\end{array}$ & $\begin{array}{c}\text { Production } \\
\text { (ton/ha) }\end{array}$ \\
\hline $\begin{array}{l}\text { Types of isolates } \\
\text { Isolate I }\end{array}$ & $0.29 \mathrm{c}$ & $2.47 \mathrm{a}$ & $29.38 \mathrm{a}$ & 21.91 \\
Isolate II & $0.17 \mathrm{~b}$ & $2.64 \mathrm{~b}$ & $29.76 \mathrm{c}$ & 22.78 \\
Isolate III & $0.15 \mathrm{a}$ & $2.78 \mathrm{c}$ & $29.70 \mathrm{~b}$ & 22.80 \\
Dosage of Nitrogen & & & & \\
Without N Fertilizer & 0.20 & $2.69 \mathrm{~b}$ & $29.69 \mathrm{~b}$ & $21.52 \mathrm{a}$ \\
N 50\% & 0.22 & $2.52 \mathrm{a}$ & $29.46 \mathrm{a}$ & $22.30 \mathrm{~b}$ \\
N 100\% & 0.18 & $2.68 \mathrm{~b}$ & $29.69 \mathrm{~b}$ & $23.67 \mathrm{c}$ \\
\hline LSD 0.05 & 0.005 & 0.019 & 0.017 & 0.20 \\
\hline
\end{tabular}

Remarks: Values followed by the same letters are not significantly different at the $5 \%$ LSD test

Isolate from culture III yielded the lowest weight of empty grains and the highest weight of filled grains. The weight of filled grains and 1000 filled grains of rice plants treated with culture microalgae III was higher than those of rice plants fertilized with $100 \%$ nitrogen. This indicates that microalgae isolate assists grain filling in the generative phase of rice plants, in which according to Winahyu et al. (2013), microalgae are used as green manures in agriculture and bioremediation that capture $\mathrm{N}_{2}$ from the air. Lestari (2017) stated that Cyanophyceae microalgae could increase the ammonium concentration in a range of $15.83 \mu \mathrm{g} \mathrm{ml}^{-1}-21.41$ $\mu \mathrm{g} \mathrm{ml}{ }^{-1}$. That means if the nitrogen requirement in swamp rice fields ranges between 40-135 $\mathrm{kg} \mathrm{ha}^{-1}$, Cyanophyceae can donate nitrogen in the form of ammonium ranging from $11.72 \%-15.86 \%$ with calculation of Cyanophyceae abundance of 106 cells $\mathrm{ml}^{-1}$ with the assumption of flooding water height on swamp land is as high as $10 \mathrm{~cm}$.

The interaction of isolate types and the dosage of $\mathrm{N}$ fertilizer showed significant effect on the percentage of empty grain and the weight of 1000 filled grains. Microalgae in a nitrogen-enriched environment will utilize the existing nitrogen without 
Table 4. The interaction effects of isolate types and dosage of $\mathrm{N}$ fertilizer on the weight of 1000 filled grains and percentage of empty grain

\begin{tabular}{cccc}
\hline \multirow{2}{*}{ Treatment } & \multicolumn{3}{c}{ Dose N (\% plants requirement) } \\
\cline { 2 - 4 } & $0 \%$ & $50 \%$ & $100 \%$ \\
\hline \multirow{3}{*}{ Isolate I } & $29.46 \mathrm{~b}$ & $29.10 \mathrm{a}$ & $29.59 \mathrm{e}$ \\
Isolate II & $29.90 \mathrm{f}$ & $29.48 \mathrm{c}$ & $29.91 \mathrm{f}$ \\
Isolate III & $29.72 \mathrm{e}$ & $29.80 \mathrm{f}$ & $29.57 \mathrm{~d}$ \\
& Percentage of empty grains (\%) \\
Isolate I & $0.27 \mathrm{e}$ & $0.30 \mathrm{f}$ & $0.29 \mathrm{e}$ \\
Isolate II & $0.16 \mathrm{~b}$ & $0.18 \mathrm{~d}$ & $0.17 \mathrm{c}$ \\
Isolate III & $0.18 \mathrm{~d}$ & $0.18 \mathrm{~d}$ & $0.08 \mathrm{a}$ \\
\hline
\end{tabular}

Remarks: Values followed by the same letters are not significantly different at the $5 \%$ LSD test

having to retard free nitrogen in the air. The ability of Cyanophyceae microalgae in non-symbiotic nitrogen inhibiting is greater when compared with non-symbiotic bacterial capability due to the ability of Cyanophyceae to adapt and inhibit nitrogen which is better than bacteria. The number of filled grains will increase with the nitrogen fixation by the microalgae so that it can meet the $\mathrm{N}$ needs of the plants.

Production of rice depends on the number of productive tillers, the weight of grain per panicle, the number of grains per panicle and its ecophysiological environmental components. The best interaction was in the treatment of isolates culture I with $50 \%$ nitrogen fertilization dose, while the lowest was in the interaction of isolates cultured III with $100 \%$ nitrogen dose. It was seen that the addition of nitrogen fertilization dose did not affect the weight of 1000 filled grains. The interaction of culture I and without nitrogen fertilization $\left(\mathrm{I}_{1} \mathrm{~N}_{1}\right)$ did not give significantly different effect from the interaction of culture I and $100 \%$ dose of $\left.\mathrm{N}_{(1} \mathrm{I}_{1} \mathrm{~N}_{3}\right)$ fertilization.

In addition to the interaction of the three treatments, other factors may also affect the formation of panicles and the grain filling of the rice plants.
According to Widiyawati et al. (2014), the number of grains of proboscis is also influenced by branching, the exertion, the number of panicles, differentiation of grain during anthesis, and the intensity of solar radiation.

\section{CONCLUSION}

The interaction of isolate types (I) and nitrogen dosage $(\mathrm{N})$ in the vegetative phase did not show any significant effect while in the generative phase had a significant effect on the weight of 1000 filled grains and the percentage of empty grain. The main effect of the type of isolate showed a significant effect on the weight of 1000 grains and rice, while the main treatment of nitrogen dose in the vegetative phase significantly affected the $\mathrm{N}$ plant level and $\mathrm{N}$ uptake per clump and significantly affected the yield component of the weight of 1000 filled grains, the weight of empty grains, and the percentage of empty grains. The main treatment without nitrogen fertilizers tended to have a significant effect on the growth and production of rice crops. This is thought to be the effect of the application of isolates on plants capable of providing nitrogen elements for the growth of rice crops. The percentage of empty grain produced in this study was relatively high (20\%). This can be caused by the influence of greenhouse environments used in the dry season.

\section{REFERENCES}

Abdulrachman, S., H. Sembiring., dan Suyamto. 2009. Pemupukan Tanaman Padi. litbang pertanian [internet]. [diunduh 2017 Agt 12]; tersedia pada: http://www.litbang.pertanian.go.id/special/ padi/bbpadi_2009_itp_05.pdf

Agustini, N. W. S. 2002. Kandungan pigmen astaxanthin dari mikroalgaBotryococcus braunnii pada berbagai penambahan nitrogen dan phosphor.Seminar Nasional XI Pendidikan Biologi FKIP UNS. 156-164.

Alavan, A., R. Hayati., \& E. Hayati. (2015). Pengaruh pemupukan terhadap pertumbuhan beberapa varietas padi gogo (Oryza sativa L.). J. Floratek. 10:61-68.

Amanina, M.A., 2011. Pengaruh pemberian strain Nostoc CPG8, CPG24, dan CIM7 terhadap pertumbuhan vegetatif dan generatif tanaman padi (Oryza sativa L.) varietas ciherang. [Skripsi]. Depok: Universitas Indonesia. 
Anggraini, F., Agus, S., \& Nurul, A (2013). Sistem tanam dan umur bibit pada tanaman padi sawah (Oryza sativa L.) varietas inpari 13. Jurnal Produksi Tanaman. 1(2): 338-976.

Damaso, M.C.T. M.S. Almeida, E. Kurtenbach, O.B. Martins, N. Pereira, Jr.,C.M.M.C. Andrade, and R.M. Albano. 2003. Optimized Expression of a Thermostable Xylanase from Thermomyces lanuginosus in Pichia pastoris. Applied Environmental Microbiology 69 (10): 6064-6072.

Fadilah, R. dan H.D. Ariesyady. 2013. Analisis kelimpahan dan keragaman mikroalga di kolam stabilisasi instalasi pengolahan air limbah berdasarkananalisis biologi konvensional dan molekuler. [Tesis]. Bandung: Institut Teknologi Bandung.

Gofar, N., S. Sandi dan A. Baehaki. 2017. Eksplorasi dan Pengembangan Mikroba Fungsional dari Rawa untuk Pertanian, Peternakan dan Produksi Enzim. Laporan Penelitian Hibah Profesi Tahun Pertama. LPPM Unsri, Indralaya.

Kasrina, S. Irawati, \&W.E. Jayanti. (2012). Ragam jenis mikroalga di air rawa Kelurahan Bentiring Permai Kota Bengkulu sebagai alternatif sumber belajar biologi SMA. Jurnal Exacta. X (1): 36-44.

Lestari, P.A., 2017. Eksplorasi potensi mikroalga asal lahan rawa non tidal land sebagai penambat nitrogen. [Skripsi]. Palembang: Universitas Sriwijaya.

Mezuan IP., Handayani \& Inoriah E. (2002). Penerapan formulasi pupuk hayati untuk budidaya padi gogo: studi rumah kaca. Jurnal IImu-ilmu Pertanian Indonesia.4(1):27-34.
Mohanan, K.V. \& C.B. Mini. 2008. Relative contributionof rice tillers of different status towards yield. Int. J.Plant. 2:9-12.

Sari, W.E. 2011. Isolasi dan identifikasi mikroalga Cyanophyta dari tanah persawahan Kampung Sampora, Cibinong, Bogor. [Skripsi]. Jakarta: UIN Syarif Hidayatullah.

Soltani, N., R.A. Khavari-Nejad, M. Tabatabaei Yazdi, \& S. Shokravi. 2007. Growth and Some Metabolic Features of Cyanobacterium FischerellaSp. FS18 in Different Combined Nitrogen Sources. Journal of Sciences, Islamic Republic of Iran. 18(2): 123-128.

Sopiah, N., A. Mulyanto \& S. Sehabudin. 2012. Pengaruh kelimpahan sel mikroalgae air tawar (Chlorella sp.) terhadap penambatan karbondioksida. J. Tek. Ling. 14(1): 1-6.

Thajuddin, N. \& G. Subramanian. 2005. Cyanobacterialdiversity and potential applications in biotechnology. Current Science. 89(1): 47-57.

Widiyawati, l., Sugiyanta., Ahmad, J., \& Rahayu, W., 2014. Peran bakteri penambat nitrogen untuk mengurangi dosis pupuk nitrogen anorganik pada padi sawah. J. Agro. 42(2): 96-102.

Winahyu, D.A., Y.A. Anggraini., E.L. Rustiati., J. Master., \&A. Setiawan., 2013. Studi Pendahuluan Mengenai Keanekaragaman Mikroalga di Pusat Konservasi Gajah, Taman Nasional Way Kambas. Jurusan Kimia. FMIPA Unila. Prosiding Semirata 2013 FMIPA Unila. 